\title{
DEVELOPMENT OF PROCEDURES FOR ENSURING THE REPAYMENT OF TAX DEBT AS A GUARANTEE OF THE FORMATION OF AN INVESTMENT CLIMATE
}

\author{
Valentyna Kutsyk ${ }^{1}$, Leonid Ostapenko ${ }^{2}$, Denys Pudryk ${ }^{3}$
}

\begin{abstract}
The right of a person to engage in economic activity on the principles of free competition, in accordance with legal requirements, is a guarantee of the prosperity of a socially oriented country. Since basic taxes and payments, which are used to set budgets of different levels, are collected from the results of such economic activity. In order to provide for the systematic performance of this constitutional obligation by taxpayers, control in the sphere of taxation, customs sphere, the corresponding state supervisory bodies function. The activity of these authorities in the majority of countries is stated as such that is aimed first of all at the provision of services to subjects of taxation and implementation of control measures on the basis of risk-oriented approach, and in the case of detection of violations - the application of tools directed to their termination and ensuring maximum prevention of the negative consequences of such violations. It is hardly possible to deny the importance of the formation of adequate tools for the control entities in this area. This being said, the quality of such tools is characterized, on the one hand, by indicators of the provision of expected budget revenues, which will allow implementing approved Government programs for social protection of the population, on the other - by the maximum focus on preserving the possibility of continuing economic activity by subjects of taxation. According to data of the World Bank that estimates the ease of doing business in 190 countries of the world in the framework of the annual survey, Ukraine holds 71st position by 10 indicators (including tax administration). In order to improve mechanisms of tax administration, especially supervisory bodies' tools for ensuring the repayment of tax debt, it is unconditional to study and search for ways of perceiving and introducing the positive experience of these countries. Methodology. The achievement of the formulated purpose is ensured by the use of the cognitive potential of the system of philosophical, general scientific and special methods. Given the aspiration for developing security measures for the repayment of tax debt, which are generally accepted and effective in terms of a specific legal system, comparative-legal method has become the main one as it allowed determining development directions of these measures taking into account the experience of countries with rather stable indicators of the economy. Methods of grammatical review and interpretation of legal rules have contributed to identifying gaps and other shortcomings in legislation that regulates the repayment of taxpayers' debts and developing proposals to improve them. Practical implications. The practice of supervisory bodies' activity can be effective provided that tools are clearly defined in laws and regulations and are understandable (both in terms of content and procedure) to all participants in the legal relationship on ensuring the repayment of tax debt. Taking into account new laws of social and economic realities that are changing rapidly under the accelerating development of information technologies, not only Ukraine but also other countries need to improve the specified area of activity of the supervisory bodies.
\end{abstract}

Key words: supervisory bodies in the economy, tax administration, effectiveness of tax debt repayment procedures, tax lien, quality of services for taxpayers.

JEL Classification: H21, H24, H71, K34

\footnotetext{
Corresponding author:

${ }^{1}$ Lviv University of Trade and Economics, Ukraine.

E-mail: valentynakutsyk@gmail.com

${ }^{2}$ Lviv Polytechnic National University, Ukraine.

E-mail: leonidostapenko89@gmail.com

${ }^{3}$ National University of State Fiscal Service of Ukraine, Ukraine.

E-mail: pudrik.nusta@ukr.net
} 


\section{Introduction}

The prosperity and proper level of social protection of the population in most European countries are connected with the systematic, continuous, and responding to the anticipated forecasts filling of budgets of different levels, achieved through a timely performance by taxpayers of their constitutional obligation to pay taxes, levies, and other obligatory charges. In states with a high standard of living, a highly developed economy, and a low corruption perceptions index, there is also a high level of timely voluntary payment of tax liabilities, either independently determined or accounted by the controlling body.

At the same time, such a level of activity of taxpayers and tax discipline is associated with key provisions in the system of tax administration, which first of all include legal regulation mechanisms for the taxpayer's tax debt repayment procedure.

Taxpayer's tax debt is rather a complicated economic and legal category. In any state, there is an unconditional well-considered approach to the formation of a mechanism for managing tax debt, including the application of a set of measures, namely: preventive measures - to eliminate circumstances that may lead to the occurrence of a tax debt, measures to ensure the performance of obligations to pay taxes by taxpayers, and direct measures for the collection of tax debt.

\section{Classification of tax debt repayment measures in Georgia, Lithuania, Estonia, Latvia, Republic of Azerbaijan, Kazakhstan, and Ukraine}

In the tax legislation of the vast majority of postSoviet countries, it is foreseen to fulfil the tax obligation: voluntarily by the taxpayer and in a compulsory manner, in the case of non-fulfilment of the tax liability by the taxpayer within the term established by law.

With regard to the latter situation, one can distinguish the initial stage of proceedings for the compulsory repayment of tax debt, which can be related to fixing the fact of the taxpayer's notification of the tax debt.

For example, in Azerbaijan, in accordance with para. 65.1 of Art. 65 of the Tax Code of the Republic of Azerbaijan, if the taxpayer fails to fulfil the tax liability within the term specified by the Tax Code of the Republic of Azerbaijan, the tax authority sends to the payer a notice of charge within five days on taxes, interest, and financial penalties applied, accrued or recalculated in accordance with the Tax Code of the Republic of Azerbaijan. Already the next step of the supervisory body is to provide a credit institution or a person who carries out banking operations with an order to collect arrears of taxes, interest, and financial penalties from the current or other accounts of the taxpayer in national or foreign currency, which is an implementation (payment) document (Tax Code of the Republic of Azerbaijan, 2000). It should be noted about the difference in the terms provided to the taxpayer to pay a tax debt (from 10 to 60 days) after informing about its existence and during which the controlling authority does not apply the enforcement measures for the amounts indicated. The maximum term is provided by the Tax Code of Ukraine and is 60 days, which, in the opinion of many researchers and practitioners, is not reasonable enough, because due to such an approach, the implementation of the tax liability is delayed, quite often taxpayers use the provided time to conceal funds and other property, at the expense of which further tax debt can be secured.

After informing about the existence of tax debt, as a rule, on the next working day, the controlling body is obliged to continue with the application of security measures. The lists of measures for securing and enforcing the tax debt vary considerably. For example, in Georgia (in accordance with Article 238 "Securing tax collection compliance by the tax authority"), it is provided that in order to secure tax collection compliance, the supervisory authorities apply the following measures: imposing a tax lien/mortgage; levying a tax on a third person; seizing property; selling seized property; presenting a collection order to a bank account; collecting cash from the cash register of the taxpayer. At the same time, it is important to focus attention on the possibility provided to the supervisory body to determine the order of application of the said measures, unless otherwise provided for by the Tax Code (Tax Code of Georgia, 2010). Unlike the abovementioned provisions, the tax authority in Ukraine, which is currently in a state of regular reform, not only has no such a specifically described instrument but is also limited in choosing the procedure for applying tax debt security and repayment measures.

Analysis of the provisions of laws and regulations of other countries (in particular, Estonia, Latvia, Lithuania, Azerbaijan, and Kazakhstan), which regulate the order of application of tax debt enforcement measures, allows suggesting that the most widespread are the measures by which, firstly, the information on debt recognition is recorded, the opportunity for the taxpayer to choose a support provider or to take advantage of the possibility of transferring the terms of payment. After that, the supervisory authority has the right to block funds on the taxpayer's accounts in banks, without permission to commit such actions in court (except for the procedure provided for by the Tax Code of Ukraine). Also, security is provided by establishing a restriction on the alienation of immovable and movable property.

\section{Features of measures to prevent the formation of tax debt and ensure the repayment of already formed one}

Attention should be paid to such procedures that, according to the purpose of the application, can be contributed as to measures preventing the formation 
of tax debt, so to measures ensuring the repayment of already formed one. In the majority of countries, these are measures, the application of which is initiated by a taxpayer itself. In accordance with the Tax Code of Ukraine, in the presence of the established list of circumstances specified by the Cabinet of Ministers of Ukraine, a taxpayer may be granted with instalment, deferral of monetary obligations or tax debt. These are the means of collateral consisting in transferring the terms of payment of taxpayers' money liabilities or tax debt at a rate equal to the amount of 120 percent annual discount rate of the National Bank of Ukraine acting on the day of the decision of the supervisory body to make a decision on instalment, deferral of monetary obligations or tax debt (Tax Code of Ukraine, 2010). The Tax Code of Estonia provides that the tax administrator, upon request of the taxable person who is experiencing the complication of tax payment, has the right to arrange payment of his tax debt on the instalments, as well as the payment of such a known liability, which term has not yet come. The subject of taxation provides a reasonable request and a payment schedule to get instalment (Article 111 of the TA of Estonia) (Taxation Act of the Republic of Estonia, 2002). The guarantee of the application of such measures, called the instalment and deferral of a tax liability or a tax debt, is called a lien (sometimes the name is specified as a taxlien) or a guaranty, according to the legislation of Ukraine - only a tax lien. It should be noted that the legislation of Ukraine restricts the taxpayer's right to use the guaranty, rather common and that is actively used in other countries. Obviously, such restrictions once again raise the issue of introducing alternative security measures with the involvement of the third parties, which require improvement of legal regulation and control over the activities of banks and other financial institutions in the country.

It is important to note the reasonableness of the approach of the Estonian legislator, who has put measures to secure and enforce the tax liability, including the repayment of tax debt, in one chapter (Chapter 12 "Security"). Among these securities, there are provided: surety, an amount of security paid into the bank account designated therefor as a deposit; a registered security over movables or a mortgage established for the benefit of the state, a rural municipality or a city (Article 122) (Taxation Act of the Republic of Estonia, 2002). A tax authority has the right to issue an order to a credit institution for the seizure of the bank account of a debtor or for the transfer of money from the bank account of a debtor to the bank account designated therefor in the amount of the tax arrears. A credit institution is required to comply without delay with such order for the seizure of the bank account of a taxable person. If the amount in the bank account is smaller than the amount to be transferred according to the order of the tax authority, the credit institution is required to comply with the order in an amount equal to the amount in this bank account and further receipts of money in the bank account of the debtor (Article 131) (Taxation Act of the Republic of Estonia, 2002).

If we turn to the Tax Code of Ukraine, then, unfortunately, we can again state that the current legal procedure is different from the given one since the supervisory body itself has the right to make decisions only in relation to the application of the tax lien of the taxpayer's property, that being said, the Code states that if the taxpayer does not allow the tax authority to make a property inventory of such a taxpayer in tax lien and/ or fails to submit the documents necessary for such an inventory, the tax authority draws up an act of refusal of the taxpayer from property inventory in tax lien and appeals to the court to stop cost transactions in the taxpayer's accounts, prohibit alienation of property by such a taxpayer, and oblige such a taxpayer to allow the tax administrator to conduct property inventory in tax lien (Tax Code of Ukraine, 2010). The relevant restrictions on the supervisory authority's powers under the legislation of Ukraine are also discussed during the characterization of measures for the compulsory collection of tax debt. The analysis of court decisions on the resolution of tax disputes allows indicating systematic practical problems related both to the specified restrictions and to the gaps in the formulation of legal regulations (first of all, provisions of the Tax Code of Ukraine) regarding types of security measures and measures to collect tax debt, procedures for their application. Scientists are talking about such problems (Tylchyk, 2011); their proposals remain unconsidered at the level of legislation, though.

Procedures for tax debt repayment are differentiated depending on the type of taxpayer. There are: repayment of a tax debt of legal entities (organizations) and individuals-entrepreneurs; repayment of a tax debt of individuals who are not subjects of economic activity.

Depending on the subject, who is obliged under the law to decide and repay a tax debt, the following procedures are allocated:

a) by judicial procedure. When the supervisory body in order to apply the procedure for repayment at the expense of the taxpayer's property must apply to the court and obtain a court decision on the repayment of tax arrears from the taxpayer.

b) under administrative procedure. The supervisory body independently applies procedures for taxpayer's tax debt repayment but, for making an appropriate decision, it pre-appeals to the court for a permit; the taxpayer has the right to appeal such actions in court.

The judicial procedure for making a decision on the application of measures to repay tax debt, as the researchers claim, guarantees a more objective consideration of the issue on a tax debt and the validity of claims of the supervisory body. At the same time, the case takes place on the principles of competition in the process, where the taxpayer more actively protects the 
rights. Such an order is more complex for supervisory bodies and requires of them good legal preparation, consideration of the case takes a considerable time. The burden on the judicial system considerably increases, and consideration of such a case requires a judge of a high level of qualifications in the field of taxation.

\section{Conclusions}

Processes of introducing new forms of interaction between the state and taxpayers are in constant development, which today is seen in an attempt to put forward a leading idea, the essence of which is to establish and observe partnership relations and socially useful results. Summarizing the above, one can conclude that countries with a legal system close to Ukraine in the issues of regulating the types and procedure for applying the tools aimed at ensuring the repayment of tax debt go through reformatting the basic approaches depending on the chosen priorities of state development at a particular historical stage. If we reflect the logical course of development of the tools of supervisory bodies in the field of taxation, in particular, the procedures for ensuring the repayment of tax debt, then two main ways can be presented. The first one to establish an institution of security means, which are maximally aimed at eliminating the alienation of the taxpayer's property (including funds and valuables in bank accounts). The decision on the use of these tools is made by the supervisory authority subject to the development of systemic and qualitative control, in the first place - judicial. The second one - to develop a set of security means aimed at creating the conditions for the continuation of the taxpayer's economic activity and expanding the circle of subjects involved in making the decision to select a specific security measure in order to exclude the occurrence of high corruption risks in the activities of supervisory bodies in this area.

\section{References:}

Ukraine has risen to 5 positions in the ranking of Doing Business-2019. Retrieved from: https://biz.liga.net/ ekonomika/all/novosti/doing-business-2019-ukraina-podnyalas-na-5-pozitsiy

Tax Code of Georgia. Retrieved from: https://matsne.gov.ge/ka

Tax Code of the Republic of Azerbaijan (Approved by Law of the Republic of Azerbaijan on July 11, 2000. № 905-IQ). Retrieved from: http://www.taxes.gov.az/modul.php?name=qanun\&cat=3\&lang=_rus

Tax Code of Ukraine. Law of Ukraine on 02.12.2010 № 2755-VI. Verkhovna Rada of Ukraine. Gazette of the Verkhovna Rada of Ukraine (GVR), 2011, № 13-14, № 15-16, № 17, Art. 112. Retrieved from: https://zakon.rada.gov.ua/laws/ show/2755-17\#n1370

Tylchyk, V. (2011). Administrative and legal mechanism for the resolution of tax disputes: thesis for Cand. Sc. (Jurisprudence): 12.00.07. Irpin.

Taxation Act of the Republic of Estonia (2002). Retrieved from: https://v1.juristaitab.ee/sites/www.juristaitab.ee/ files/elfinder/ru-seadused 